УДК (39 (=161.2):004.87):37-048.35

\author{
Філіпчук Георгій Георгійович \\ доктор педагогічних наук, професор, дійсний член (академік) НАПН України \\ Національна академія педагогічних наук України, м. Київ, Україна \\ ORCID ID 0000-0001-7397-0874 \\ georg.filipchuk@gmail.com
}

\author{
Вовк Мирослава Петрівна \\ доктор педагогічних наук, \\ старший науковий співробітник, завідувач відділу змісту і технологій педагогічної освіти \\ Інститут педагогічної освіти і освіти дорослих імені Івана Зязюна НАПН України, м. Київ, Україна \\ ORCID ID 0000-0002-9109-9194 \\ miravovk79@gmail.com

\section{Котун Кирил Васильович} \\ кандидат педагогічних наук, \\ старший науковий співробітник відділу зарубіжних систем педагогічної освіти і освіти дорослих \\ Інститут педагогічної освіти і освіти дорослих імені Івана Зязюна, м. Київ, Україна \\ ORCID ID 0000-0002-3661-6689 \\ smartk@ukr.net \\ Ходацька Ольга Миколаївна \\ вчитель-методист гімназії-інтернату №13 м. Києва, аспірантка \\ Інститут педагогічної освіти і освіти дорослих імені Івана Зязюна, м. Київ, Україна \\ ORCID ID 0000-0003-0559-535X \\ omhodatska@gmail.com
}

\title{
ПОТЕНЦАЛ УКРАЇНОЗНАВЧИХ ЕЛЕКТРОННИХ РЕСУРСІВ У ПЕДАГОГІЧНІЙ ОСВІТІ: ДОСВІД УКРАЇНИ І КАНАДИ
}

\begin{abstract}
Анотація. У статті схарактеризовано потенціал електронних українознавчих ресурсів у контексті модернізаційних змін у сфері педагогічної освіти. Уточнено сутність поняття «українознавчі ресурси» як сукупності джерелознавчих праць, наукових розвідок, збірників та ін., що представлено у вимірах суміжних наук (етнопедагогіки, етнології, культурології, лінгвістики, фольклористики, краєзнавства, народознавства, етнографії, історії, джерелознавства тощо) та власне українознавчих дисциплін (українська мова, українська література, українська культура, історія України тощо) у реальному (бібліографічному, архівному) та віртуальному контекстах. Схарактеризовано досвід систематизації українознавчих електронних ресурсів в Канаді, що уможливило виокремлення таких прогресивних досягнень: створення загальнодержавного інтернет-порталу українознавства, заснування віртуальних бібліотек, центрів і лабораторій при університетах тощо.

Студіювання сучасних електронних українознавчих ресурсів в українському і канадському віртуальному просторі уможливило виокремлення таких їх категорій: електронні навчальні бібліотеки й архіви, віртуальні лабораторії при університетах, українознавча періодика 3 їх представленням на вебсторінках чи сайтах університетських і академічних осередків, реферативні бази.

Спроєктовано можливості використання електронних українознавчих ресурсів 3 урахуванням сучасних модернізаційних змін у педагогічній освіті на двох рівнях - на університетському (створення i розвиток ресурсних центрів, вебсайтів, порталів, електронних бібліотек; упровадження тематичних модулів, які розкривають віртуальний простір теорії і практики українознавчих студій; розміщення в електронних архівах матеріалів за результатами фольклористичної практики) i на шкільному (створення ресурсних баз на основі наявних українських і канадських українознавчих електронних джерел; активізація дослідницької роботи учнів - членів Малої академії наук України, заснування під егідою Міністерства освіти i науки України інтернет-порталу українознавства з урахуванням потреб сучасного вчителя і учня).
\end{abstract}

Ключові слова: електронні українознавчі ресурси; потенціал; модернізація; педагогічна освіта; Канада; Україна. 


\section{1. ВСТУП}

Постановка проблеми. 3-поміж вагомих пріоритетів модернізації сучасної педагогічної освіти актуалізується проблема створення інноваційного інформаційного простору, що передбачає якісні зміни в професійній підготовці сучасного вчителя шляхом опанування ресурсів українознавчих наук, представленого у реальному та віртуальному інформаційному просторі. Неперервний розвиток сучасного педагога, формування його як людини культури, агента змін, інноваційної особистості передбачає створення ефективних умов для професійного зростання, особистісного саморозвитку через використання потенційних можливостей сучасного інформаційного суспільства. Серед важливих засобів формування спектру фахових компетентностей сучасного вчителя - українознавчі електронні ресурси, використання яких в освітньому процесі дозволить значно оновити зміст, форми і методи професійної підготовки майбутніх учителів, насамперед учителів-філологів, білінгвістів. Тому в сучасному українознавчому науково-освітньому дискурсі набуває актуальності проблема систематизації надбань українознавчих наук у віртуальному контексті, що значною мірою пов'язано 3 необхідністю репрезентування здобутків українознавчих студій у міждисциплінарному вимірі та освітньої практики вивчення українознавства, суголосних дисциплін в університетах, в академічних осередках України і Канади. Актуальність використання українознавчих електронних ресурсів у закладах вищої педагогічної освіти зумовлена потребою створення цифрового освітнього простору, потребою активізації самостійної пізнавальної і дослідницької діяльності, забезпечення умов для формальної та інформальної освіти майбутніх педагогів.

Нині лише окреслюється тенденція систематизації українознавчих досліджень, практико орієнтованих праць - досягнень з українознавчих наук у синхронічному i діахронічному контексті, що виявляється в заснуванні електронних баз даних, електронних архівів, віртуальних лабораторій, сайтів періодичних видань українознавчого спрямування при університетах, наукових осередках в Україні i Канаді. Насамперед канадський досвід створення i популяризації українознавчих студій, здійснення і презентування у віртуальному просторі міждисциплінарних українознавчих наукових праць, освітніх видань, періодики може стати для української освіти взірцем ефективної реалізації державної політики підтримки розвитку культури, науки, освітніх традицій, мови однієї з найбільш потужних українських діаспор. Однак у сфері педагогічної освіти недостатньою мірою використовується потенціал електронних українознавчих ресурсів України і Канади, зокрема у процесі вивчення українознавчих дисциплін, активізації дослідницької діяльності, самоосвіти майбутніх учителів, що значно загальмовує модернізаційні зміни у підготовці сучасного вчителя, насамперед учителя-філолога.

Аналіз останніх досліджень і публікацій. У результаті студіювання спектру джерелознавчих праць, наукових розвідок, віртуальних джерел було виявлено, що проблема використання потенціалу електронних ресурсів українознавчого спрямування не була предметом цілісного вивчення. Так, у сучасному педагогічному дискурсі значна увага приділена проблемі теоретико-методологічного обгрунтування можливостей використання інформаційно-комунікативних технологій, ресурсів Інтернет-мережі в педагогічній освіті (О. Кучерук, С. Караман, О. Караман, Н. Віннікова [1] та ін.). 3-поміж відомих праць виокремлюються дослідження, у яких приділяється увага проблемі їх використання у процесі підготовки i підвищення кваліфікації вчителя-філолога (О. Семеног [2], М. Ячменик [3] та ін.). У філологічному дискурсі є фрагментарні розвідки, присвячені проблемі створення електронних ресурсів українознавчого спрямування в Україні (А. Вовчак [4]) і Канаді (Т. Білущак, А. Пелещишин та С. Альбота [5]). 
Мета статті - схарактеризувати потенціал електронних українознавчих ресурсів у контексті модернізаційних змін у сфері педагогічної освіти. Мета дослідження конкретизується в таких завданнях:

1) уточнити сутність понять «українознавчі ресурси», «українознавчі електронні ресурси»;

2) проаналізувати сучасні електронні українознавчі ресурси в українському i канадському віртуальному просторі 3 метою окреслення їх потенціалу у процесі оновлення змісту, форм і методів, ресурсного забезпечення професійної підготовки сучасного вчителя;

3) виявити можливості використання електронних українознавчих ресурсів 3 урахуванням сучасних модернізаційних змін у педагогічній освіті.

\section{2. ТЕОРЕТИЧНІ ОСНОВИ ДОСЛІДЖЕННЯ}

Ретроспектива становлення українознавства охоплює другу половину XIX перші десятиліття XXI ст.: завдяки іменам М. Максимовича, I. Котляревського, Т. Шевченка, П. Куліша, І. Франка, Ф. Сушицького, М. Драгоманова, М. Грушевського та ін. діячів сформувалася теорія і практика українознавчих студій. Еволюційний розвиток українознавства пов'язаний з поступом українознавчих, філологічних наук в Україні і Канаді, що зумовлено плідною науковою й освітньою діяльністю вчених, педагогів-українознавців. Так, сучасними осередками розвитку українознавства 6 Україні є такі установи: Інститут народознавства НАН України, Інститут фольклористики, мистецтвознавства і етнології імені М. Рильського НАН України, Науково-дослідний інститут українознавства Міністерства освіти і науки України, Львівський національний університет імені Івана Франка, Київський національний університет імені Тараса Шевченка та ін.; y Kaнадi - Канадський Інститут Українських Студій, Центр дослідження української спадщини в Саскачеванському університеті (Канада); Центр українського і канадського фольклору ім. Кулів Альбертського університету (Канада), Світовий Конгрес Українців та ін.

У науковому дискурсі вживаються суголосні 3 поняттям «українознавство» терміносполуки: україніка, україністика, народознавство, суспільствознавство, краєзнавство, батьківщинознавство, етнопедагогіка, народна педагогіка, етнографія та iн. Уперше як окрему науково-освітню галузь українознавство виокремив Ф. Сушицький, який її розглядав як галузь наукової роботи, що роз'яснює минуле й сучасне життя українського народу, пояснює його національні особливості, його територію, різні впливи життя нашого народу та його розвиток, його мову, творчість взагалі, художню й літературну зокрема («Принципи українознавства», Вільна украӥнська школа, Вип. 2, С. 82-88, 1917).

Структуру українознавчих дисциплін уперше визначили I. Стешенко i О. Дорошкевич (1918) у «Матеріалах до вивчення предметів українознавства», до яких зараховували такі: 1. Історія України на нижчих щаблях освіти. 2. Історія України в середніх ланках освіти. 3. Історія України «до курсу вищого концентру». 4. Програма курсу української мови i літератури. 5. Проєкт програми географії (природи i населення) України: а) для середніх навчальних закладів; б) для старших класів середніх навчальних закладів. 3 1930-х рр. в Україні поняття «українознавство було вилучено 3 активного наукового вжитку. Однак на першому українському педагогічному Конгресі у Львові в 1935 р. В. Пачевський виступив із доповіддю «Українознавство у вихованні молоді», де до цієї науки зарахував українську мову, літературу, пластичне мистецтво, музику та «географію земель, заселених українцями»[6]. 
Відродження українознавства як унікальної наукової галузі розпочалося в 1990x pp., що пов'язано із здобуттям Україною незалежності. У цей період завдяки українським освітянам, науковцям (П. Кононенко, Т. Усатенко, Л. Дунаєвська, Т. Комаринець та ін.) українознавство набуло фундаментального наукового обгрунтування та впроваджувалося в освітню практику (у багатьох університетах майбутні вчителі-філологи здобували бінарну спеціальність «вчитель української мови і літератури, українознавства», курс з українознавства вивчали в багатьох закладах середньої освіти тощо).

Сучасні дослідники визначають українознавство як цілісну систему знань про Україну і світове українство, як наукову систему, що передбачає врахування принципу історизму, якомога повнішого джерелознавства вітчизняного і зарубіжного, єдності аналізу, синтезу досліджень уроків минулого та проблем сучасності і на тій основі прогноз і планування майбутнього (П. Кононенко [7]), як систему етнологічних, культурологічних, етнопедагогічних, історичних та інших досліджень про український народ у його минулому та сучасному розвитку (В. Оліфіренко [8]).

Студіювання наукових джерел уможливило обгрунтування авторської дефініції українознавства як міждисциплінарної науково-освітньої галузі, що в історичній ретроспективі сформувалася на основі когнітивного, естетичного, етичного, релігійного досвіду українства 3 урахуванням теорії і практики суміжних наук, передбачає здійснення українознавчих студій в українських осередках й інституціях української діаспори та вивчення українознавчих дисциплін у закладах середньої, вищої освіти й організацію мистецьких практик (опанування ремесел, вишивання, писанкарство, хореографічне мистецтво та ін.) українознавчого спрямування у виховній діяльності в умовах формальної і неформальної освіти.

Відповідно украӥнознавчі ресурси - це сукупність джерелознавчих праць, наукових розвідок, збірників і та ін., що представлено у вимірах суміжних наук (етнопедагогіки, етнології, культурології, лінгвістики, фольклористики, краєзнавства, народознавства, етнографії, фольклористики, історії, джерелознавства тощо) та власне українознавчих дисциплін (українська мова, українська література, українська культура, історія України тощо) у реальному (бібліографічному, архівному) та віртуальному контекстах. На основі студіювання сучасних наукових праць сформульовано власну дефініцію украӥнознавчих електронних ресурсів. Це наукові, навчально-методичні, довідково-енциклопедичні праці, періодичні видання, архівні джерела, представлені в електронній або оцифрованій формах, і розміщені на сайтах, веб-сторінках, в електронних бібліотеках, на інтернет-порталах, в електронних архівах наукових інституцій, університетів, дослідницьких центрів, музеїв та інших організацій, діяльність яких спрямована на розвиток українознавчих студій, створення $\mathrm{i}$ популяризацію здобутків українознавства та інших суміжних наук в науковому й освітньому середовищі.

\section{3. МЕТОДИКА ДОСЛІДЖЕННЯ}

Реалізації мети і завдань сприяло обрання спектру методів: контент-аналізу - для студіювання електронних українознавчих ресурсів в Україні і Канаді; теоретичного аналізу - 3 метою визначення сутнісних характеристик понять «українознавство», «українознавчі ресурси», «українознавчі електронні ресурси» тощо; методу наукової екстраполяції - для виявлення можливостей використання потенціалу електронних українознавчих ресурсів в умовах модернізації педагогічної освіти.

Відповідно дослідження відбувалося у два етапи: на теоретико-пошуковому етапі здійснювалося студіювання джерелознавчого матеріалу в реальному та віртуальному 
просторі, теоретичне узагальнення поняттєвого апарату дослідження; на емпіричнодіяльнісному етапі було схарактеризовано потенціал електронних українознавчих ресурсів з урахуванням сучасних модернізаційних змін у педагогічній освіті.

\section{4. РЕЗУЛЬТАТИ ДОСЛІДЖЕННЯ}

У зв'язку 3 модернізаційними процесами в педагогічній освіті (створення ресурсних центрів при університетах, впровадження дистанційної форми навчання тощо) посилюється значення електронних освітніх і наукових ресурсів, що значно активізує освітній процес, зумовлює інтенсифікацію пізнавальної, самостійної творчої, дослідницької роботи майбутніх учителів, викладачів-дослідників. Суголосні виклики спостерігаються i у підготовці сучасного вчителя, викладача української мови i літератури в закладах вищої педагогічної освіти і класичних університетах (відповідно до Стандартів вищої освіти за спеціальністю 035 «Філологія» у галузі «Гуманітарні науки» на бакалаврському і магістерському рівнях, затверджених 2019 р.).

Нині маємо значні напрацювання в практичній реалізації ідеї заснування електронних ресурсів українознавчого спрямування в Україні і Канаді. Водночас потенціал вже створених ресурсів недостатньою мірою використовується у більшості закладів вищої освіти, що нівелює потенційні можливості якісної професійної підготовки майбутнього філолога, не сприяє прогресивному розвиткові віртуального філологічного простору в Україні і світі.

Перша віртуальна лабораторія українознавчого спрямування - лабораторія фольклористичних досліджень - створена викладачами кафедри фольклористики імені Філарета Колесси Львівського національного університету імені Івана Франка, у якій представлені найвагоміші, знакові праці 3 історії становлення науковофольклористичних шкіл, традицій збирання й архівування фольклорних текстів тощо [9]. Репрезентуючи історію створення лабораторії та інших суголосних структур, А. Вовчак зазначає, що упродовж 2012-2014 років Лабораторія фольклористичних досліджень у співпраці з Кафедрою та із залученням фахівця інформаційних технологій реалізувала ідею електронного архівування фольклорної традиції (за фінансової підтримки Міністерства освіти і науки України; учасники проєкту - професор Василь Івашків, доцент Андрій Вовчак, магістри Роман Сулим, Марія Папіш, Оксана Шутка).

31 жовтня 2014 р. запрацював Електронний архів украйнського фольклору (http://folklore-archive.org.ua) 3 метою розміщення польових фольклорних матеріалів 3 метою їх фахового дослідження та культурно-просвітницького використання. Структурно й функціонально Електронний архів українського фольклору організовано на матеріалах та 3 урахуванням досвіду праці Фольклорного архіву Кафедри української фольклористики [10].

Крім того, викладачі кафедри фольклористики імені Філарета Колесси створили електронну навчальну бібліотеку української фольклористики [11]. Фундаментальність оцифрованого книжкового електронного фонду полягає в наявності в ньому видань (фотодруків) відомих дослідників народної культури другої половини XIX - першої половини XX ст. Це перший бібліографічний покажчик за авторством Б. Грінченка (1901), праці Ф. Колесси («Українська усна словесність» (1938) та ін.), Г. Нудьги, М. Костомарова, П. Житецького, М. Сумцова та ін.; збірники фольклорних жанрів, укладені В. Гнатюком, О. Роздольським, «Запорожская старина», «Русалка Дністровая»; випуски періодики різних років («Етнографічний вісник», «Матеріали 3 української етнології», «Етнографічний збірник») та ін. Досвід львів’ян підтверджує ефективність грунтовного вивчення і студіювання майбутніми філологами першоджерел на основі використання потенціалу електронної навчальної бібліотеки, що сприяє формуванню 
мотивації щодо здійснення подальшої наукової українознавчої діяльності, усвідомлення необхідності передавання українознавчих досягнень в освітній практиці.

Студіювання електронних віртуальних ресурсів (вебсторінок, сайтів тощо) уможливило з'ясувати, що в сучасному науково-педагогічному середовищі українознавча періодика представлена у двох вимірах: академічному («київська», «львівська», «волинська» в межах діяльності інститутів НАН України) та університетському (Київський національний університет імені Тараса Шевченка, Львівський національний університет імені Івана Франка, Донецький національний університет імені Василя Стуса, Черкаський національний університет імені Богдана Хмельницького). Можливості використання наукових студій, практичних розробок у процесі підготовки вчителя-філолога, суттєво збагачуються за рахунок імплементації матеріалів періодичних видань, що розташовані на вебсторінках.

Потенціал українознавчої періодики грунтується на трансляційному механізмі передавання наукового й освітнього досвіду в ретроспективі, ретрансляцією досягнень українознавчої думки у закладах освіти. У періодичних виданнях визначаються методологічні та практичні засади осмислення, інтерпретації українознавчих реалій, що вивчаються в міждисциплінарному контексті, характеризуються можливості впровадження інновацій в освітню практику вивчення теорії і практики українознавства.

Схарактеризуємо потенціал сучасної українознавчої періодики, репрезентованої у віртуальному просторі. Сучасні українознавчі видання представлені кількома авторитетними часописами, збірниками праць. «Київську» академічну періодику представляє журнал «Народна творчість та етнологія» [12], що має тривалу історію функціонування (засновано як «Етнографічний вісник» 31925 р. за редакцією А. Лободи та В. Петрова, у 1936 - 1939 рр. - «Український фольклор», з 1939 р. «Народна творчість», а 31947 р. - наукові записки «Мистецтво. Фольклор. Етнографія» (чотири томи), з 1950-х pp. - «Народна творчість і етнографія», 32010 р. - сучасна назва). У журналі висвітлено результати контекстного вивчення українського фольклору, етнографії, народного образотворчого мистецтва, матеріали з культурології, музикознавства, театрознавства, кінознавства тощо. Постійні рубрики часопису («Розвідки і матеріали», «3 історії науки і культури», «Наука і сучасність», «3 архівів, колекцій, рідкісних видань», «Трибуна молодого дослідника», «Нариси та етюди», «Огляди, рецензії, анотації») репрезентують розвиток фольклористики на основі історично сформованих вітчизняних науково-практичних здобутків та зарубіжного досвіду дослідження фольклору, етнографічної специфіки. Матеріали часопису інформують про діяльність зарубіжних українознавчих осередків, про напрями дослідження фольклорної традиції у світовій практиці. Спецвипуски «НТЕ» присвячені висвітленню результатів наукової співпраці українських та румунських етнологів, фольклористів, зініційованої Українським етнологічним центром Інституту мистецтвознавства, фольклористики і етнології імені М. Рильського НАН України; здобуткам турецької фольклористики як результату співпраці з Інститутом фольклору Університету Газі (м. Анкара); досягненням російської фольклористики, зокрема, Інституту етнології та антропології імені М.М. Миклухи-Маклая РАН; дослідженню теорії і практики македонської фольклористики, іiі осередку - Інституту фольклору ім. М. Цепенкова (Скоп’є) та ін. Досвід видання часопису підтверджує традицію репрезентації наукових результатів, збиральницької роботи, проблем співпраці 3 зарубіжними інституціями, що визначає потенціал ресурсу в напрямі оновлення змісту професійної підготовки майбутніх учителів-філологів.

Збірник наукових праць Інституту мистецтвознавства, фольклористики та етнології ім. М. Рильського НАН України «Матеріали до української етнології» [13] видавався упродовж 1929 - 1931 рр., засновниками видання були Комісія краєзнавства, 
Всеукраїнське етнографічне товариство, Історико-філологічний відділ АН УР СР, а потім відновлено випуск з 2007 р. У збірнику традиційно публікується матеріал 3 iсторії, теорії та практики етнологічних досліджень, водночас фольклористична проблематика аналізується у контексті сучасних етнологічних пошуків учених України і зарубіжжя. У процесі вивчення дисциплін українознавчого спрямування майбутній філолог, фольклорист може ознайомитися із сучасними результатами регіонального дослідження фольклору, з працями, присвяченими аналізу взаємовпливу фольклорних традицій різних культур, з аналітичними студіями, у яких висвітлено проблеми ролі особистості в історії розвитку фольклористики тощо.

«Львівська» українознавча періодика представлена «Народознавчими зошитами», журналом «Міфологія і фольклор», «Вісником Львівського університету» (серія філологічна, фольклористична). Найактуальніша проблематика «Народознавчих зошитів» [14] (з 1995 р., Інститут народознавства НАН України (м. Львів)) - різні аспекти етнології, фольклористики, мистецтвознавства, культурології, лінгвістики, літературознавства, етнопсихології, історії, археології, соціології та інших суспільногуманітарних наук. За роки існування видано ряд спеціальних та тематичних випусків «Народознавчих зошитів»: «Хрестологія» (2000), «Студії з інтегральної культурології 1: Thanatos» (1996) та «Студії з інтегральної культурології 2: Ritual» (1999), «10 років Чорнобильської трагедії» (1996), «Актуальні питання мистецтвознавства», «Архітектура та архітектурознавство». Окремі випуски присвячено ювілеям видатних учених-співробітників інституту: Ю. Гошка, М. Станкевича, Р. Захарчук-Чугай, Р. Кирчіва, Г. Дем'яна, В. Овсійчука та класиків вітчизняної науки В. Сас-Залозецького, Р. Гарасимчука.

Важливо відзначити, що засновники журналу пов'язують його виникнення 3 інтенсифікацією народознавчих наук, 3 необхідністю активізації наукового, педагогічного співробітництва різних українських і зарубіжних інституцій. Саме тому на сторінках журналу виходять друком статті, які представляють напрями досліджень різних інституційних осередків, зокрема українознавчих. Проблематика матеріалів свідчить про функціональний, контекстний підхід до висвітлення процесу становлення народознавчих наук.

Подібна специфіка висвітлення результатів дослідницьких пошуків науковців властива іншому періодичному виданню фольклористично-етнографічного спрямування - журналу «Міфологія і фольклор» (2008-2013 рр.), засновникамивидавцями якого $€$ викладачі Львівського національного університету імені Івана Франка та члени Українського товариства дослідників фольклору та міфології. Головна мета цього періодичного видання - «сприяти підвищенню наукового рівня досліджень і публікацій нових текстів фольклору та міфології, які є важливим духовним надбанням українського народу; публікувати дослідження у параметрах теорії та методології фольклору, історії фольклористики, поетики, символіки й етноестетики фольклору; створення для українського читача інформативно місткого і мобільного науковоосвітнього часопису, в якому висвітлюється широке коло проблем, окреслених діадою «міфологія - фольклор» [15].

Засновники методологічно обгрунтовано підійшли до номінування часопису, відповідно до якого матеріал диференціюється залежно від тенденційної проблеми: багатоаспектний аналіз фольклорних текстів, висвітлення питань історії фольклористики, літературознавчі дослідження у контексті фольклоризму та міфологізму в художній літературі, лінгвофольклористичні студії, рецензії i відгуки на найновіші фольклористичні видання. Важливо відзначити, що на сторінках журналу, у рубриці «Фольклор у середній та вищій школі» вміщуються статті з проблем змісту вивчення фольклористики, методики викладання фольклору у навчальних закладах різного типу. 
У Львівському національному університеті імені І. Франка з ініціативи викладачів кафедри фольклористики імені Ф. Колесси виходять друком спецвипуски «Вісника Львівського університету», присвячені проблемам українознавчих студій («Українська фольклористика» - у 1999 р., 2003 р., 2006 р., 2007 р., 2009 р., 2017 р. Зміст і структурування матеріалів випусків збірника свідчать про розвиток наукових традицій львівського фольклористичного осередку. Необхідно відзначити, що матеріали випусків видавці адресовують науковцям, викладачам, студентам філологічних факультетів та вчителям-практикам. Акцентується увага на теоретико-методологічних засадах аналізу фольклорних текстів, на принципах їх архівування та систематизації, на історичному досвіді розвитку української фольклористики, на внеску українських учених, викладачів у розвиток слов'янських, європейських фольклористичних студій, на представленні результатів дослідження регіонального фольклорного середовища, на досягненнях фольклористичної науки і практики в результаті співпраці з міжнародними інституціями тощо [16].

«Волинська» фольклористично-етнографічна періодика представлена авторитетним виданням «Фольклористичні зошити» (1996 - 2010 рр., засновник Інститут культурної антропології НАН України (м. Луцьк) [17]. Проблематика часопису (рубрики «Іеологія фольклору», «Історіософія фольклору», «Фольклористичне архівознавство», «Фольклористична регіоналістика», «Порівняльна фольклористика», «Історія фольклористики», «Публікації», «Перша ластівка») зорієнтована на представлення функціонального виміру дослідження фольклору: фольклор у зв'язках з обрядовістю, ритуальною організацією життєдіяльності суспільства, фольклор у вимірах антропологічних досліджень, фольклор як чинник впливу на авторську літературу, фольклор у контексті діалектологічного аналізу тощо. На його сторінках періодично друкуються статті, в яких висвітлено результати наукової, збиральницької фольклористичної діяльності Інституту культурної антропології, викладачів і студентів Східноєвропейського національного університету імені Лесі Українки, що може стати орієнтиром у контексті оновлення змісту і форм фольклористичної практики у педагогічних університетах.

У 1993 р. 3 ініціативи викладачів кафедри фольклористики Інституту філології Київського національного університету імені Тараса Шевченка засновано збірник «Література. Фольклор. Проблеми поетики» [18]. Наукова проблематика збірника актуальні проблеми дослідження теорії фольклору, жанрології, поетики окремих жанрів, фольклорно-літературних зв'язків, літературознавства, маловідомих фактів наукової діяльності фольклористів, літературознавців, етнографів. У збірнику репрезентуються результати сучасної наукової фольклористичної думки України i зарубіжжя: здійснюється ретроспективний аналіз витоків фольклористики, наукових шкіл, окремих аспектів освітньої практики вивчення фольклору, представлені текстологічні дослідження фольклорних текстів, інтерферентні зв'язки фольклору 3 різними видами мистецтва Необхідно відзначити, що це авторитетне видання покликане інформувати наукову та освітянську громадськість про специфіку дослідження українського, слов'янського, європейського фольклору у контексті функціонального, контекстного, комунікативного, культурологічного підходів, що свідчить про загальносвітові та європейські пріоритети аналізу фольклорного досвіду.

Викладачів кафедри української літератури та фольклористики Донецького національного університету імені Василя Стуса стали ініціаторами видання збірника «Актуальні проблеми української літератури і фольклору» (заснований 1998 р., виходить двічі на рік), присвяченого висвітленню літературознавчих $\mathrm{i}$ фольклористичних проблем філологічних наук на сучасному етапі. У збірнику вміщено матеріали 3 питань дослідження жанрології, поетики фольклору, фольклоризму 
літератури, 3 визначення внеску персоналій у розвиток фольклористики, диференційовано представлено проблеми систематизації, узагальнення досвіду вивчення фольклору Східного регіону України [19].

3 середини 2000-х pp. у Черкаському національному педагогічному університеті імені Богдана Хмельницького завдяки ініціативі викладачів кафедри української літератури періодично виходить друком збірник наукових праць «Літературознавство. Фольклористика. Культурологія» (3 2011 р.). Його мета - «дослідження різнобічних науково-літературознавчих проблем у загальнонаціональному та світовому контекстах, актуальних проблем української фольклористики, культурології, методики викладання літератури в навчальних закладах» [20]. Проблематика видання засвідчує спрямованість на дослідження фольклору як синкретичного явища культури, на висвітлення результатів аналізу фольклорної спадщини у вимірах суміжних наук, на представлення проблем інтердисциплінарності розвитку сучасної фольклористики.

Загалом педагогічний потенціал сучасної українознавчої періодики полягає в можливості ознайомлення 3 сучасними досягненнями фольклористичної наукової думки (проблеми лінгвофольклористики, текстології, жанрології фольклору, історії фольклористики, регіональні дослідження фольклору, інноваційні засади вивчення фольклорного досвіду тощо), представлення результатів сучасних академічних й університетських фольклористичних осередків та здобутків зарубіжних інституцій.

У сучасному українському науково-освітньому дискурсі спостерігається тенденція створення реферативних баз даних, що дозволяє значно оновити зміст українознавчих дисциплін у сфері педагогічної освіти. Основними аспектами оновлення має стати вивчення персонології українознавчих студій, активізація дослідницької роботи майбутніх педагогів на основі вивчення маловідомих фактів, матеріалів українознавчих наук у синхронічному i діахронічному аспектах, регіоналістики українознавчих досліджень, досягнень української діаспори в напрямі систематизації дослідницьких матеріалів зі субдисциплін українознавства тощо.

Так, національна реферативна база даних «Україніка наукова» заснована 1998 р. $€$ диференційованим за галузями знань та інтегрованим у масштабах країни сучасним інформаційним продуктом, дає змогу здійснити прогнозування розвитку наукового знання в Україні на основі даних, що відображають динаміку розширення рубрик галузевого розподілу публікацій 3 подальшим проведенням бібліометричних досліджень вихідного потоку видань 3 необхідної тематики [21]. «Україніка наукова» створена для піднесення авторитету української науки вирішувати завдання оперативного розповсюдження української наукової періодики в зарубіжних сучасних наукових комунікаціях. Реферативна база даних заснована з урахуванням тенденції введення бібліометричної основи для обліку й оцінювання ефективності науки за допомогою наукометричного аналізу (наприклад, Google Scholar, Web of Science, SciVers Scopus, Index Copernicus, Astrophysics, Inspec, Pub Med, Mathematics, Chemical Abstracts, Springer та ін.). Основні функції «Україніки наукової» - формування національних реферативних ресурсів; підготовка до друку галузевих серій Українського реферативного журналу «Джерело»; активізація входження України до міжнародної системи наукових електронних комунікацій. Фундаторами і виконавцями «Україніки наукової» є Інститут реєстрації інформації НАН України, Національна бібліотека України імені В.І. Вернадського, Державна науково-педагогічна бібліотека ім.В.О. Сухомлинського, Національна наукова медична бібліотека України. Посилаючись на закордонний досвід, фундатори РБД «Україніка наукова» Національна бібліотека України ім. В.І. Вернадського та Інститут реєстрації інформації НАН України спільно з іншими вітчизняними науковцями в галузі інформаційних технологій розмірковують над перспективами розвитку національної системи реферування 
України та різними аспектами надання послуг, зокрема бібліо- й наукометричних [22]. Отже, тенденція до створення реферативних баз на прикладі «Україніки наукової» сприяє систематизації українознавчих студій насамперед на рівні персонології українознавчих наук, зокрема щодо забезпечення вільного доступу до інформації про результати наукової діяльності вітчизняних учених і їх представлення в міжнародному науково-освітньому українознавчому вимірі.

Вагомий потенціал, що слугує суттєвим чинником модернізації педагогічної освіти, насамперед підготовки майбутніх філологів, мають електронні бібліотеки, що значно розширює можливості «анурення» майбутніх фахівців в аксіокультурне наукове середовище українознавчих студій, створює можливості для ознайомлення з надбаннями зарубіжних i українських осередків, діяльність яких спрямована на розвиток українознавчих субдисциплін. Потужний потенціал збагачення змісту через студіювання українознавчого джерелознавчого, науково-теоретичного, практико орієнтованого матеріалу має Електронна бібліотека «Культура України», створена на основі Національної бібліотеки імені Ярослава Мудрого. Мета заснування бібліотеки (з 2011 р.) зумовлена власне стратегічною перспективою імплементації досягнень українознавчої наукової думки і освітньої практики українознавчих дисциплін в сучасному науковоосвітньому середовищі в українському i міжнародному контексті, що полягає в забезпеченні: «інтеграції культури народів України у європейський i світовий інформаційний простір, зміцнення культурних зв'язків і формування позитивного іміджу України у світі; рівної можливості безкоштовного доступу користувачів до надбань української культури і мистецтва за допомогою Інтернет мережі; надання користувачам якісно нових можливостей роботи з інтегрованим інформаційним ресурсом бібліотек, музеїв та інших закладів культури в єдиній точці доступу; створення електронних копій друкованих документів для збереження культурної спадщини, що знаходиться у фондах бібліотек та інших закладів культури та запобігання фізичного зносу документів; ефективності використання документів, розкриття фондів бібліотек, музеїв, архівів та інших закладів культури з питань культури і мистецтв» [23].

3-поміж багатьох країн світу унікальний досвід створення, продукування i популяризації електронних ресурсів українознавчого спрямування, що має на меті систематизувати українознавчі наукові, навчально-методичні, віртуальні праці, періодику із субдисциплін українознавства, суміжних наук, має Канада. Так, Т. Білущак, А. Пелещишин та С. Альбота в колективній монографії «Україна - Канада: сучасні наукові студії» (2018) систематизували електронні українознавчі джерела на шість основних груп: 1) архівні, бібліотечні та музейні ресурси; 2) вебсайти найважливіших дослідницьких українознавчих інституцій; 3) величезний масив інформації, який надається численними віртуальними спільнотами та соціальними мережами в Інтернеті; 4) вебенциклопедії та вебпортали; 5) інтернет-версії електронних медіа; шоста група надає нам базу бібліографічних та оглядових даних [24].

На особливу увагу заслуговує створена науковцями, освітянами, громадськими діячами електронна українознавча енциклопедія (Internet Encyclopedia of Ukraine), заснована 3 ініціативи Канадського інституту дослідження України Альбертського університету [25]. Ця енциклопедія вирізняється інтерактивністю структурування матеріалу із залученням широкого джерелознавчого матеріалу (авторських текстів, збірників за результатами збиральницької діяльності відомих українознавців етнографів, культурологів, лінгвістів тощо на етнічних українських землях та в зарубіжжі (зарубіжна україністика). Іншим ресурсом у канадському віртуальному просторі, що сприяє висвітленню різних аспектів соціального, культурного, науково-освітнього розвитку українства в Канаді і світі, є електронна бібліотека «Diasporiana», місія якої полягає у збереженні зацікавленими українознавцями з усього світу досягнень теорії i 
практики українознавства - в оцифрованому вигляді на громадських засадах - наукових праць, збірників фольклорних текстів, архівних документів тощо [26].

З 1997 p. у канадському українознавчому середовищі створено Консорціум україномовної освіти, місією якого $є$ реалізація українознавчих проєктів 3 метою створення віртуального українознавчого навчального середовища, що зумовлено необхідністю узагальнення і популяризації онлайн-ресурсів з українознавчих дисциплін (мови, літератури, історії, культури, неформальне навчання різним видам мистецтва на українознавчій основі тощо). Водночас Консорціум координує діяльність мережі українознавчих інституцій на рівні університетів, громад, провінцій, тому забезпечує ознайомлення вчительської спільноти 3 навчальними програмами, навчальнометодичними виданнями для двомовних і «рідних» шкіл Канади з дитячого садка до 12 класу) [27]. Діяльність Консорціуму спрямована також на утвердження партнерських взаємин між осередками, організаціями, інституціями, що сприяють просуванню українознавчих проєктів у світі, поширенню конструктивних ідей зарубіжного досвіду організації віртуального українознавчого простору і слугує підтвердженням активного використання інформаційно-комунікативних технологій в українознавчому дискурсі діаспори і України.

Передумовою створення Консорціуму україномовної освіти стала діяльність Центру україномовної освіти Канадського інституту українських студій та його допоміжного підрозділу - Методичного кабінету української мови, заснованих 1987 р. Стратегічною метою цих осередків від початку функціонування стало задоволення професійних потреб вчительської спільноти в забезпеченні освітніми ресурсними матеріалами з українознавчих дисциплін, насамперед української мови для початкової і середньої школи, розвиток віртуального простору теорії і практики українознавчих дисциплін 3 урахуванням специфіки шкільної освіти в умовах двомовного білінгвального навчання. 3 цією метою українознавці акцентували увагу на створенні аудіо- і відеоматеріалів для вчителів. Діяльність цих осередків стала основою створення Інтернет-порталу українознавства, зокрема онлайн-центру з україномовного навчання для студентів, учителів і батьків.

На основі аналізу електронних українознавчих ресурсів в українському i канадському віртуальному просторі обгрунтовано можливості конструктивного використання їх потенціалу в умовах сучасних модернізаційних змін у сфері педагогічної освіти на двох рівнях - університетському і шкільному.

На університетському рівні доцільно використовувати електронні ресурси українознавчого спрямування 3 метою модернізації педагогічної освіти - оновлення змісту, форм і методів підготовки сучасного вчителя-філолога. Ці фахівці мають опанувати потенціал українознавчих наук, їх субдисциплін, суміжних галузей знань, відповідно ретранслювати українознавчий досвід теорії й освітньої практики громадськості, учнівській і студентській молоді. Відповідно вони мають бути наділені високим рівнем інформаційної, технологічної культури, чому має сприяти врегулювання взаємодії університетів і наукових інституцій щодо створення ресурсної бази 3 українознавчих наук, створення і розвиток ресурсних центрів, вебсайтів, порталів, електронних бібліотек з проблем українознавчих студій, українознавчої освіти; посилення якості підготовки на основі структурування змісту українознавчих дисциплін 3 урахуванням їх міждисциплінарності, добору матеріалів 3 метою інтенсифікації дослідницької, проєктної, наукової роботи на основі використання електронних ресурсів 3 проблеми персонології вітчизняного i зарубіжного українознавства. Доцільно впроваджувати у зміст дисциплін українознавчого спрямування тематичні модулі, які розкривають віртуальний простір теорії і практики українознавчих студій в українських і зарубіжних осередках - університетах, музеях, 
центрах тощо. 3 цією метою на філологічних факультетах мають створюватися віртуальні лабораторії з проблем українознавства за взірцем Львівського національного університету імені Івана Франка. Видання і розміщення у віртуальному просторі періодичних видань українознавчого спрямування у зв'язку з посиленням автономного статусу університетів і наукових установ має забезпечуватися інституційно. Водночас $\epsilon$ потреба розроблення практикумів, творчо-пошукових, дослідницьких завдань у підготовці вчителя-філолога шляхом студіювання матеріалів періодичних видань, ознайомлення за їх допомогою 3 досягненням сучасної українознавчої науки, спродукованою в закордонному і українському дискурсі.

На шкільному рівні доцільно створювати ресурсні бази на основі наявних українських i канадських українознавчих електронних джерел 3 метою оновлення змісту українознавчих дисциплін, активізації позанавчальних заходів шляхом використання досвіду двомовного навчання в Канаді на основі вивчення віртуальних ресурсів Центру україномовної освіти. Активізація дослідницької роботи учнів - членів Малої академії наук України на основі поглибленого вивчення віртуальних джерел 3 теорії i практики українознавчих студій значно уможливить створення когорти молодих українознавців-дослідників, чия діяльність буде спрямована на вивчення i збагачення інтердисциплінарного розвою українознавства. $€$ необхідність створення під егідою Міністерства освіти і науки України інтернет-порталу українознавства 3 урахуванням потреб сучасного вчителя і учня, який має формуватися як особистість 3 громадянською світоглядною позицією, спрямованою на збереження і збагачення викристалізованих традицій українознавства в Україні і зарубіжжі, що представлено зокрема й у віртуальному просторі.

\section{5. ВИСНОВКИ ТА ПЕРСПЕКТИВИ ПОДАЛЬШИХ ДОСЛІДЖЕНЬ}

У науково-освітньому дискурсі України і Канади спостерігається тенденція систематизації результатів теорії і практики українознавчих студій у реальному i віртуальному вимірах. Вивчення досвіду узагальнення досягнень українознавчих субдисциплін, суміжних наук дало змогу уточнити сутність поняття «українознавчі ресурси» як сукупності джерелознавчих праць, наукових розвідок, збірників, що представлено у вимірах суміжних наук (етнопедагогіки, етнології, культурології, лінгвістики, фольклористики, краєзнавства, народознавства, етнографії, фольклористики, історії, джерелознавства тощо) та власне українознавчих дисциплін (українська мова, українська література, українська культура, історія України тощо) у реальному (бібліографічному, архівному) та віртуальному контекстах. На основі студіювання сучасних наукових праць українознавчі електронні ресурси визначаються як наукові, навчально-методичні, довідково-енциклопедичні праці, періодичні видання, архівні джерела, представлені в електронній або оцифрованій формах, і розміщені на сайтах, веб-сторінках, в електронних бібліотеках, на інтернет-порталах, в електронних архівах наукових інституцій, університетів, дослідницьких центрів, музеїв та інших організацій, діяльність яких спрямована на розвиток українознавчих студій, створення і популяризацію здобутків українознавства та інших суміжних наук в науковому й освітньому середовищі.

Студіювання сучасних електронних українознавчих ресурсів в українському $\mathrm{i}$ канадському віртуальному просторі уможливило виокремлення таких їх категорій: електронні навчальні бібліотеки, віртуальні лабораторії при університетах, українознавча періодика 3 їх представленням на вебсторінках окремих інституцій (університетських і академічних осередків) чи сайтах тощо. Спостерігається тенденція узагальнення наукових, навчальних, видавничих праць, публікацій з українознавчих 
субдисциплін шляхом створення українознавчих реферативних баз («Україніка наукова»). Аналіз схарактеризованих ресурсів створив підстави для висновку про їх вагомий педагогічний потенціал у напрямі оновлення змісту, форм i методів професійної підготовки майбутніх учителів-філологів, які мають гнучко реагувати на сучасні виклики інформаційного суспільства, бути аксіологічно спрямованими на ретрансляцію українознавчого досвіду в освітній практиці, впроваджувати i збагачувати конструктивні ідеї систематизації надбань українського і зарубіжного українознавства. Вивчення ресурсного забезпечення українознавчих наук Канади у віртуальному середовищі сприяло виокремленню прогресивних досягнень: створення загальнодержавного інтернет-порталу українознавства, заснування віртуальних бібліотек, центрів і лабораторій при університетах, сприяння розвитку української громади як унікальної етнічної спільноти шляхом державної підтримки двомовного навчання через заснування електронних навчальних ресурсів тощо.

Спроєктовано можливості конструктивного використання потенціалу електронних українознавчих ресурсів з урахуванням сучасних модернізаційних змін у педагогічній освіті на двох рівнях: на університетському (врегулювання взаємодії університетів і наукових інституцій щодо створення ресурсної бази з українознавчих наук, створення i розвиток ресурсних центрів, вебсайтів, порталів, електронних бібліотек i архівів, віртуальних бібліотек 3 проблем українознавчих студій, українознавчої освіти; посилення якості підготовки педагогів-філологів на основі структурування змісту українознавчих дисциплін 3 урахуванням їх міждисциплінарності, добір матеріалів 3 метою інтенсифікації дослідницької, проєктної, наукової роботи на основі використання електронних ресурсів з проблеми персонології вітчизняного і зарубіжного українознавства; упровадження тематичних модулів, які розкривають віртуальний простір теорії і практики українознавчих студій в українських i зарубіжних осередках - університетах, музеях, центрах тощо; розроблення практикумів, творчо-пошукових, дослідницьких завдань у підготовці педагогів, викладачів шляхом студіювання матеріалів українських і зарубіжних періодичних видань; забезпечення можливостей розміщення фольклорних матеріалів студентами в результаті проходження фольклористичної практики) і на шкільному (створення ресурсних баз на основі наявних українських і канадських українознавчих електронних джерел з метою оновлення змісту українознавчих дисциплін, активізації позанавчальних заходів шляхом використання досвіду двомовного навчання в Канаді на основі вивчення віртуальних ресурсів Центру україномовної освіти; активізація дослідницької роботи учнів - членів Малої академії наук України, заснування під егідою Міністерства освіти і науки України інтернет-порталу українознавства 3 урахуванням потреб сучасного вчителя і учня).

Перспективою подальших наукових розвідок має стати вивчення можливостей електронних українознавчих ресурсів у країнах Європи, що уможливить представленість надбань українознавчих субдисциплін у європейському просторі в сучасній педагогічній освіті, зокрема у підготовці сучасного філолога.

\section{СПИСОК ВИКОРИСТАНИХ ДЖЕРЕЛ}

[1] О. А. Кучерук, С. О. Караман, О. В. Караман, Н. М. Віннікова, «Використання ІКТ для формування фахових компетентностей у майбутніх учителів української мови і літератури», Інформаційні технологї $i$ засоби навчання, Том 71, №3, 2019. [Електронний ресурс]. Доступно: https://journal.iitta.gov.ua/index.php/itlt/article/view/2814/1496

[2] О. М. Семеног, «Підготовка майбутніх учителів української мови і літератури до організації дозвіллєвої діяльності старшокласників засобами медіаосвіти», Педагогічні науки: теорія, історія, 
інноваційні технологї, №4, С. 215-225, 2018. [Електронний ресурс]. Доступно: http://nbuv.gov.ua/UJRN/pednauk_2018_4_21

[3] М. Ячменник, «Підготовка майбутніх учителів-словесників до використання засобів медіаосвіти у професійній діяльності: розробка моделі та ії експериментальна перевірка», Педагогічні науки: теорія, історія, інновачійні технологї, №5, С. 281-293, 2018. [Електронний ресурс]. Доступно: http://nbuv.gov.ua/UJRN/pednauk_2018_5_28.

[4] А. С. Вовчак, «Документування українського фольклору у Львівському університеті імені Івана Франка», Вісник Львівського університету. Серія філологічна, Вип. 66, С. 150-194, 2017. [Електронний pесурс]. Доступно: http://nbuv.gov.ua/UJRN/Vlnu_fil_2017_66_7.

[5] T. Bilushchak, A. Peleshchyshyn, \& S. Albota, «Using Information and Communication Capacity of Media for the Electronic Archive Formation Process to Promote Historical and Cultural Heritage of the Ukrainian Diaspora in Canada», In Ukraine - Canada: Modern Scientific Studies: Collective Monograph (in three books), Book 3, pp. 13-33, Lutsk: Vezha-Druk, 2018.

[6] Т. Усатенко, «Епістеміологія українознавства: педагогічний контекст», Кіровоград, Імекс-ЛТД, 2014, $128 \mathrm{c}$.

[7] П. Кононенко, «Історія українознавства», Київ, Академічне видавництво, 2011, 512 с.

[8] Енциклопедія українознавства для школярів і студентів, авт.-уклад. В. В. Оліфіренко [та ін.], Донецьк, Сталкер, 1999, 496 c.

[9] Лабораторія фольклористичних досліджень Львівського національного університету імені Івана Франка [Електронний ресурс]. Доступно: http://labs.lnu.edu.ua/folklore-studies/

[10] А. С. Вовчак, «Документування українського фольклору у Львівському університеті імені Івана Франка», Вісник Львівського університету. Серія філологічна, Вип. 66, С. 150-194, 2017. [Електронний pесурс]. Доступно: http://nbuv.gov.ua/UJRN/Vlnu_fil_2017_66_7.

[11] Електронна навчальна бібліотека української фольклористики при кафедрі української фольклористики імені Філарета Колесси [Електронний ресурс]. Доступно: http://www.lnu.edu.ua/faculty/Philol/www/laboratory_folk_studies/lab_folk_el_library.php.

[12] Науковий журнал «Народна творчість та етнологія» [Електронний ресурс]. Доступно: https://nte.etnolog.org.ua/

[13] Матеріали до української етнології [Електронний ресурс]. Доступно: http://mue.etnolog.org.ua/zmist.html

[14] Народознавчі зошити [Електронний ресурс]. Доступно: https://nz.lviv.ua/

[15] Міфологія і фольклор: загальноукраїнський науково-освітній журнал [Електронний ресурс]. Доступно: http://mifgournal.Inu.edu.ua/index.php/home_uk.html

[16] Вісник Львівського університету. Серія: філологічна [Електронний ресурс]. Доступно: http://publications.lnu.edu.ua/bulletins/index.php/philology

[17] Фольклористичні зошити. Збірник наукових праць [Електронний ресурс]. Доступно: http://dspace.nbuv.gov.ua/handle/123456789/14127

[18] Література. Фольклор. Проблеми поетики: збірник наукових праць [Електронний ресурс]. Доступно: https://philology.knu.ua/nauka/publicatsiyna_actyvnist/vydannya_if/lit-folk-probl-poet/

[19] Актуальні проблеми української літератури i фольклору [Електронний ресурс]. Доступно: http://www.irbis-nbuv.gov.ua/cgi-

bin/irbis_nbuv/cgiirbis_64.exe?Z21ID=\&I21DBN=JRN\&P21DBN=JRN\&S21STN=1\&S21REF=10\&S21FM $\mathrm{T}=$ fullwebr $\& \mathrm{C} 21 \mathrm{COM}=\mathrm{S} \& \mathrm{~S} 21 \mathrm{CNR}=20 \& \mathrm{~S} 21 \mathrm{P} 01=0 \& \mathrm{~S} 21 \mathrm{P} 02=0 \& \mathrm{~S} 21 \mathrm{P} 03=\mathrm{I}=\& \mathrm{~S} 21 \mathrm{COLORTERMS}=1 \& \mathrm{~S} 2$ $1 \mathrm{STR}=\% \mathrm{D} 0 \% 9670397 \$$

[20] Літературознавство. Фольклористика. Культурологія: збірник наукових праць [Електронний ресурс]. Доступно:

http://www.irbis-nbuv.gov.ua/cgibin/irbis_nbuv/cgiirbis_64.exe?Z21ID=\&I21DBN=UJRN\&P21DBN=UJRN\&S21STN=1\&S21REF=10\&S21 $\mathrm{FMT}=$ juu_all $\& \mathrm{C} 21 \mathrm{COM}=\mathrm{S} \& \mathrm{~S} 21 \mathrm{CNR}=20 \& S 21 \mathrm{P} 01=0 \& S 21 \mathrm{P} 02=0 \& S 21 \mathrm{P} 03=\mathrm{PREF}=\& \mathrm{~S} 21 \mathrm{COLORTERMS}$ $=0 \& S 21 \mathrm{STR}=\mathrm{Lfk}$.

[21] Н. Я. Зайченко, «Бібліометрика у реферативній БД «Україніка наукова», Адаптація завдань $і$ функцій наукової бібліотеки до вимог розвитку ичифрових інформаційних ресурсів, Матеріали міжнар. наук. конф., Київ, 8-10 жовт. 2013 р., С. 338-340, 2013.

[22] Реферативна база даних «Україніка наукова». [Електронний ресурс]. Доступно: http://www.nbuv.gov.ua/data_base.

[23] Електронна бібліотека «Культура України» (Національна бібліотека імені Ярослава Мудрого). [Електронний ресурс]. Доступно: https://elib.nlu.org.ua/

[24] T. Bilushchak «The media's capacity as archives and primary sources to promote historical and cultural heritage of the Ukrainian Diaspora in Canada» Ukraine - Canada: the Materials of the First International Scholarly and Practical Congress on Canadian Studies (June 21-24, 2018, Lutsk, Ukraine), Lutsk, VezhaDruk, 2018, P. 33-37.

[25] Internet Encyclopedia of Ukraine. [Електронний ресурс]. Доступно: http://www.encyclopediaofukraine/ 
[26] Diasporiana Електронна бібліотека. [Електронний ресурс]. Доступно: http://diasporiana.org.ua/

[27] Ukrainian Knowledge Internet Portal (UkiP) Consortium Association. [Електронний ресурс]. Доступно: https:/uccab.ca/ukrainian-knowledge-internet-portal-ukip-consortium-association/

Матеріал надійшов до редакиї 21.12.2019 p.

\title{
ПОТЕНЦИАЛ УКРАИНОВЕДЧЕСКИХ ЭЛЕКТРОННЫХ РЕСУРСОВ В ПЕДАГОГИЧЕСКОМ ОБРАЗОВАНИИ: ОПЫТ УКРАИНЫ И КАНАДЫ
}

\author{
Филипчук Георгий Георгиевич \\ доктор педагогических наук, профессор, действительный член (академик) НАПН Украины \\ Национальная академия педагогических наук Украины, г. Киев, Украина \\ ORCID ID 0000-0001-7397-0874 \\ georg.filipchuk@gmail.com \\ Вовк Мирослава Петровна \\ доктор педагогических наук, \\ старший научный сотрудник, заведующая отдела содержания и технологий педагогического образования \\ Институт педагогического образования и образования взрослых имени Ивана Зязюна НАПН Украины, \\ г. Киев, Украина \\ ORCID ID 0000-0002-9109-9194 \\ miravovk79@gmail.com
}

\section{Котун Кирилл Васильевич}

кандидат педагогических наук, старший научный сотрудник отдела зарубежных систем

педагогического образования и образования взрослых

Институт педагогического образования и образования взрослых имени Ивана Зязюна, г. Киев, Украина

ORCID ID 0000-0002-3661-6689

smartk@ukr.net

\section{Ходацкая Ольга Николаевна}

учитель-методист гимназии-интерната №13 м. Киева, аспирантка,

Институт педагогического образования и образования взрослых имени Ивана Зязюна НАПН Украины, г. Киев, Украина

ORCID ID 0000-0003-0559-535X

omhodatska@gmail.com

\begin{abstract}
Аннотация. В статье охарактеризован потенциал электронных украиноведческих ресурсов в контексте модернизационных изменений в сфере педагогического образования. Уточнена сущность понятия «украиноведческие ресурсы» как совокупности источниковедческих работ, научных исследований, сборников и т. п., представленого в измерениях смежных наук (этнопедагогики, этнологии, культурологии, лингвистики, фольклористики, краеведения, народоведения, этнографии, истории, источниковедения и т. д.) и собственно украиноведческих дисциплин (украинский язык, украинская литература, украинская культура, история Украины и т.д.) в реальном (библиографическом, архивном) и виртуальном контекстах.

Охарактеризован опыт систематизации украиноведческих электронных ресурсов в Канаде, что позволило выделить такие прогрессивные достижения: создание общегосударственного интернет-портала украиноведения, виртуальных библиотек, центров и лабораторий при университетах.

Изучение современных электронных украиноведческих ресурсов в украинском и канадском виртуальном пространстве позволило выделить такие их категории: электронные учебные библиотеки и архивы, виртуальные лаборатории при университетах, украиноведческая периодика с их представлением на вебстраницах или сайтах университетских и академических центров, реферативные базы и т.п.

Спроектированы возможности использования электронных украиноведческих ресурсов с учетом современных модернизационных изменений в педагогическом образовании на двух уровнях - на университетском (создание и развитие ресурсных центров, вебсайтов, порталов, электронных библиотек; внедрение тематических модулей, которые раскрывают виртуальное пространство теории и практики украиноведческих студий; размещение в
\end{abstract}


электронных архивах материалов по результатам фольклористической практики) и на школьном (создание ресурсных баз на основе имеющихся украинских и канадских украиноведческих электронных источников; активизация исследовательской работы учеников - членов Малой академии наук Украины, основания под эгидой Министерства образования и науки Украины интернет-портала украиноведения с учетом потребностей современного учителя и ученика).

Ключевые слова: электронные украиноведческие ресурсы; потенциал; модернизация; педагогическое образование; Канада; Украина.

\title{
UKRAINIAN ELECTRONIC RESOURCES POTENTIAL FOR PEDAGOGICAL EDUCATION: EXPERIENCE OF UKRAINE AND CANADA
}

\author{
Heorhiy H. Philipchuk \\ Doctor of Pedagogical Sciences, Professor, Full Member (Academician) of the NAES of Ukraine \\ National Academy of Educational Sciences of Ukraine, Kyiv, Ukraine \\ ORCID ID 0000-0001-7397-0874 \\ georg.filipchuk@gmail.com
}

\section{Myroslava P. Vovk}

Doctor of Pedagogical Sciences, Senior Researcher,

The Head of the Department of Pedagogical Education Content and Technologies

Ivan Ziaziun Institute of Pedagogical and Adult Education NAES of Ukraine, Kyiv, Ukraine

ORCID ID 0000-0002-9109-9194

miravovk79@gmail.com

\section{Kyryl V. Kotun}

PhD of Pedagogical Sciences,

Senior Researcher at the Department of Foreign Systems of Pedagogical and Adult Education Ivan Ziaziun Institute of Pedagogical and Adult Education NAES of Ukraine, Kyiv, Ukraine ORCID ID 0000-0002-3661-6689

smartk@ukr.net

\section{Olha M. Khodatska}

teacher-methodologist at the boarding school №13 in Kyiv, PhD student

Ivan Ziaziun Institute of Pedagogical and Adult Education NAES of Ukraine, Kyiv, Ukraine

ORCID ID 0000-0003-0559-535X

omhodatska@gmail.com

\begin{abstract}
The article describes the potential of electronic Ukrainian resources in the context of modern changes in the field of pedagogical education. The article clarifies the term of "Ukrainian resources" as a set of source studies, scientific researches, work collections, etc., presented in related sciences (ethnopedagogy, ethnology, culturology, linguistic, folk studies, study of Motherland, study of nation, ethnography, history, resource study) and in Ukrainian disciplines (Ukrainian Language, Ukrainian Literature, Ukrainian Culture, History of Ukraine, etc.) in real (bibliographic, archival) and virtual contexts.

The authors also study Canada's experience of Ukrainian electronic resources systematisation, which made it possible to single out such progressive achievements as a nationwide Internet portal of Ukrainian resources, virtual libraries, university centers and laboratories.

The analysis of modern electronic Ukrainian resources in Ukrainian and Canadian virtual space allows distinguishing the following categories: electronic training libraries and archives, university virtual laboratories, Ukrainian periodicals with their presentation on university or academic web sites.

The paper suggests the possibilities of using the electronic Ukrainian resources taking into account modern changes in pedagogical education at two levels - at university level (creation and development of resource centers, websites, portals, electronic libraries; implementation of thematic modules that reveal the virtual space of Ukrainian theories; electronic archives of materials based on folklore practice) and at the school level (creation of resource bases on available Ukrainian and Canadian electronic sources; revitalization of pupils research work -
\end{abstract}


members of the Junior Academy of Sciences of Ukraine, the foundation of Internet portal on the Ukrainian study which meets the modern pupils' and teachers' needs).

Keywords: electronic resources; electronic Ukrainian resources; Ukrainian Studies; virtual space; modernization; pedagogical education; Canada; Ukraine.

\section{REFERENCES (TRANSLATED AND TRANSLITERATED)}

[1] O. A. Kucheruk, S. O. Karaman, O. V. Karaman, and N. M. Vinnikova, "Use of ICT for the formation of professional competences in future teachers of Ukrainian language and literature", Information Technologies and Learning Tools, vol. 71, №3, 2019. [Online]. Available: https://journal.iitta.gov.ua/index.php/itlt/article/view/2814/1496. (in Ukrainian)

[2] O. M. Semenoh, "Future teachers training of Ukrainian language and literature for the organization of leisure activities of high school students by of media education means", Pedagogichni nauky: teoriia, istoria, innovatsii, tehnologii, №4, pp. 215-225, $2018 . \quad$ [Online]. Available: http://nbuv.gov.ua/UJRN/pednauk_2018_4_21. (in Ukrainian)

[3] M. Yachmennyk, "Future teachers training in field of vocabulary for the use of media education in their professional work: model development and experimental testing", Pedagogichni nauky: teoriia, istoria, innovatsii, tehnologii, №5, pp. 281-293, 2018. [Online]. Available: http://nbuv.gov.ua/UJRN/pednauk_2018_5_28. (in Ukrainian)

[4] A. S. Vovchak, "Documentation of Ukrainian folklore at Ivan Franko Lviv University", Visnyk Lvivskoho universytetu. Seriia fililogichna, vol.66, pp.150-194, 2017. [Online]. Available: http://nbuv.gov.ua/UJRN/Vlnu_fil_2017_66_7.(in Ukrainian)

[5] T. Bilushchak, A. Peleshchyshyn, and S. Albota, "Using Information and Communication Capacity of Media for the Electronic Archive Formation Process to Promote Historical and Cultural Heritage of the Ukrainian Diaspora in Canada", In Ukraine - Canada: Modern Scientific Studies: Collective Monograph (in three books), Book 3, pp. 13-33, Lutsk: Vezha-Druk, 2018. (in English)

[6] T. Usatenko, Epistemology of Ukrainian Studies: A Pedagogical Context, Kirovohrad, Imeks-LTD, 2014, 128 p.

[7] P. Kononenko, The History of Ukrainian Studies, Kyiv, Akademichne vydavnytstvo, 2011, 512 p. (in Ukrainian)

[8] V. V. Oliphirenko et al (Ed.), Encyclopedia of Ukrainian Studies for Schoolchildren and Students, Donetsk, Stalker, 1999, 496 p. (in Ukrainian)

[9] Laboratory of Folklore Studies in Ivan Franko Lviv National University. [Online]. Available: http://labs.Inu.edu.ua/folklore-studies/. (in Ukrainian)

[10] A. S. Vovchak, "Documentation of Ukrainian folklore at Ivan Franko Lviv University", Visnyk Lvivskoho universytetu. Seria fililogichna, vol. 66, pp. 150-194, 2017. [Online]. Available: http://nbuv.gov.ua/UJRN/Vlnu_fil_2017_66_7. (in Ukrainian)

[11] Electronic Training Library of Ukrainian Folklore Research at Filaret Kolessa Department of Ukrainian Folklore $\quad$ Research [Online]. Available: http://www.lnu.edu.ua/faculty/Philol/www/laboratory_folk_studies/lab_folk_el_library.php. - Zaholovok z ekranu. - (in Ukrainian)

[12] Scientific journal «Narodna tvotchist ta etnologia» [Online]. Available: https://nte.etnolog.org.ua/. (in Ukrainian)

[13] Materials on Ukrainian Ethnology [Online]. Available: http://mue.etnolog.org.ua/zmist.html. (in Ukrainian)

[14] National Notebooks [Online]. Available: https://nz.lviv.ua/. (in Ukrainian)

[15] Mythology and Folklore: A Ukrainian Scientific and Educational Journal [Online]. Available: http://mifgournal.lnu.edu.ua/index.php/home_uk.html. (in Ukrainian)

[16] Bulletin of the Lviv University. Series: Philological [Online]. Available: http://publications.Inu.edu.ua/bulletins/index.php/philology. (in Ukrainian)

[17] Folklore notebooks. Zbirnyk naukovykh prats [Online]. Available: http://dspace.nbuv.gov.ua/handle/123456789/14127. (in Ukrainian)

[18] Literature. Folklore. Problems of poetics: zbirnyk naukovykh prats [Online]. Available: https://philology.knu.ua/nauka/publicatsiyna_actyvnist/vydannya_if/lit-folk-probl-poet/. (in Ukrainian)

[19] Actual problems of Ukrainian literature and folklore: zbirnyk naukovykh prats [Online]. Available: http://www.irbis-nbuv.gov.ua/cgi-

bin/irbis_nbuv/cgiirbis_64.exe?Z21ID=\&I21DBN=JRN\&P21DBN=JRN\&S21STN=1\&S21REF=10\&S21FM $\mathrm{T}=$ fullwebr\&C21COM=S\&S21CNR=20\&S21P01=0\&S21P02=0\&S21P03=I=\&S21COLORTERMS=1\&S2 $1 \mathrm{STR}=\% \mathrm{D} 0 \% 9670397 \$$. (in Ukrainian) 
[20] Literary Studies. Folklore. Cultural Studies: zbirnyk naukovykh prats [Online]. Available: http://www.irbisnbuv.gov.ua/cgi-

bin/irbis_nbuv/cgiirbis_64.exe?Z21ID=\&I21DBN=UJRN\&P21DBN=UJRN\&S21STN=1\&S21REF=10\&S21 FMT $=$ juu_all $\& C 21 \mathrm{COM}=\mathrm{S} \& S 21 \mathrm{CNR}=20 \& S 21 \mathrm{P} 01=0 \& S 21 \mathrm{P} 02=0 \& S 21 \mathrm{P} 03=\mathrm{PREF}=\& \mathrm{~S} 21 \mathrm{COLORTERMS}$ $=0 \& S 21 \mathrm{STR}=\mathrm{Lfk}$. (in Ukrainian)

[21] N.Ya. Zaichenko, "Bibliometric in the reference data base "Ukrainika naukova", Adaptatsia zavdan I funktsii naukovoi biblioteky do vymog rozvytku tsyfrovyh informatsiynyh resursive, Materialy mizhnar. nauk. konf., Kyiv, 8-10 zhovt. 2013, pp. 338-340, 2013. (in Ukrainian)

[22] Reference data base "Ukrainika naukova". [Online]. Available: http://www.nbuv.gov.ua/data_base. (in Ukrainian)

[23] E-library "Kultura Ukrainy" (Natsionalna biblioteka imeni Yaroslava Mudrogo) [Online]. Available: https://elib.nlu.org.ua/. (in Ukrainian)

[24] T. Bilushchak, "The media's capacity as archives and primary sources to promote historical and cultural heritage of the Ukrainian Diaspora in Canada" in Ukraine - Canada: the Materials of the First International Scholarly and Practical Congress on Canadian Studies (June 21-24, 2018, Lutsk, Ukraine), Lutsk, VezhaDruk, 2018, pp. 33-37. (in English)

[25] Internet Encyclopedia of Ukraine. [Online]. Available: http://www.encyclopediaofukraine/

[26] Diasporiana E-library. [Online]. Available: http://diasporiana.org.ua/. (in English)

[27] Ukrainian Knowledge Internet Portal (UkiP) Consortium Association. [Online]. Available: https://uccab.ca/ukrainian-knowledge-internet-portal-ukip-consortium-association/. (in English).

\section{(cc) EY-NC-SA}

This work is licensed under Creative Commons Attribution-NonCommercial-ShareAlike 4.0 International License. 